\title{
Europe's Salt Marshes: Urgent Need for Protective Network of Reserves
}

Salt marshes are still mercifully widespread in Europe, and protect such treasures as the 'wild' horses of the Camargue, the Andalusian bulls of the Coto Donana, the waterfowl of the Wadden Sea, the Venice lagoon, and the north coast of Norfolk. They also characterize the heads of Scottish lochs and Scandinavian fjords. Yet to the consumer, salt marshes are apt to be merely places for grazing cattle and sheep, and in fact grazing and mowing are among the traditional uses made of coastal salt marshes.

In the manner of other 'marginal' activities, old-style farming of European salt marshes is in sharp decline. The typical 'tangy' butter from the cows, and the meat and wool of sheep reared 'between land and sea', are doomed to become increasingly rare. The end result: the attractive landscapes that support this extensive form of farming are being gradually erased from Europe's shoreline.

\section{Some Notable Examples}

In the course of the last five centuries, the United Kingdom's salt marshes have dwindled from 1,000 to 450 sq. $\mathrm{km}$, particularly after 'reclamation' in the Wash and on the Essex coast. This is unfortunately but one example among many others that have alarmed naturalists, and is why a survey of salt marshes has recently been carried out by the Council of Europe's European Committee for the Conservation of Nature and Natural Resources.

While historical prestige of the Bay of Mont SaintMichel in Brittany makes it relatively safe from upheaval, other outstanding natural environments are likely to disappear. The above mainly botanists' survey of European salt marshes is accordingly accompanied by an appeal to Europeans' ecological conscience. For what would Les Saintes-Maries-de-la-Mer be like without the pink flamingoes (Phoenicopterus antioporum), the Adriatic coast without the Black-winged Stilts (Himantopus himantopus) of the salt-flats, southern Italy without its herds of buffalo? Gone are many salt marshes of Great Britain, where Brant Geese (Branta bernicla), Widgeon (Mareca penelope), and Teal (Anas creca), were wont to graze. Gone are the nesting Redshank (Totanus totanus), Shelduck (Tadorna tadorna), and Common Reed Bunting (Emberiza schoeniclus), to name but a few!

To the public at large, waterbirds are the living element of the coastline - a continuous spectacle for the numerous ornithologists of northern Europe. But behind this 'aerial ballet', the biological back-up is necessarily evident, with terrestrial plants providing pioneer vegetation from just below the high-water mark. In these daily-submerged parts are plant communities dominated by such grasses as Puccinellia maritima. This maritime grassland harbours plants which tolerate salt, benefit from strong sun, and are spared the competition of plants which are sensitive to salt. Such plants provide food not only for livestock and birds, but also for wild rabbits and hares, as well as voles (Microtus spp.) and other rodents.

\section{Tiny Animals Too}

There is more in the salt marshes than meets the naked eye-in particular miriad tiny creatures that cannot be observed through binoculars but only under a magnifying glass or even a microscope. A teeming world of some 400 animal species, that defy counting, includes the polychaete worm Nereis diversicolor, which may number some 600 individuals to the square metre. A tiny snail may number 120,000 to the square metre, and a crustacean even 400,000 to the same area!
Above the mudflats and sandy beaches, plant life bècomes more firmly established, forming the salt marshes themselves. The fauna is here more diversified, numbering in Europe some 850 species, with the crustaceans being replaced principally by insects.

\section{Widespread Services}

Salt marshes in fact cover a wide variety of habitatshuddled along rocky coastlines, spanning hundreds of square kilometres of beach, or bordering inland salt-lakes. Their productivity, measured in terms of biomass, is substantial and widely underestimated. How many people know that estuarine salt marshes store mud and treat sewage, and may receive more than 100 tonnes per hectare per year of silt and organic matter?

Salt marshes also provide grazing for cattle, havens for human rest, and grounds for breeding and feeding a great many birds. As a result, they are much sought after for recreation by amateur ornithologists and animal photographers. Similarly, scientists find in these salty and brackish environments highly specialized and adapted plants and animals. Coastal and inland salt marshes also function like islands in providing geographically isolated habitats whose plant or animal communities are of particular interest to geneticist: in them they are able to study genetic deviations.

\section{- yet Widespread Threats}

Stock farmers, amateur naturalists, and scientists, thus have a common interest in natural phenomenon which are unfortunately difficult to evaluate. Like other wet environments, salt marshes are apt to be discredited-especially in Italy, where the pretext of 'malaria control' is used as an excuse for eliminating such inland 'unhealthy areas'. 'Improvement' by drainage is, for example, transforming the small coastal lagoon at Salinella, in common with many Mediterranean sites.

Along southern Europe's popular and overpopulated coasts, salt marshes are disappearing beneath marinas and other tourist facilities. But the Spanish, French, and Italian, coasts are not the only ones: in northern Europe, too, leisure activities are a threat to certain salt marshes, as for example in Ireland near Dublin. Elsewhere, they are the victims of dock extensions and industrial development, as in the case of Poole Harbour and in the Tees estuary in England.

The oil industry has directly condemned the estuary of the Cromarty in Scotland, and indirectly affected a number of places in Brittany, through oil spillages. Salt marshes are spared nothing: pollution by urban sewage and waste from intensive pig-farming may disturb their natural state even where other human activities do not. Successive engineering works have swallowed up the salt marshes on the Bay of Aiguillon, while reservoir dams are planned for several Breton estuaries. Now the example of the tidal powerstation at Rance in France may be emulated by a tidal installation on the Severn in Britain.

\section{Some Examples Remain}

Despite these depredations, the list of salt marshes remains long, although extensive examples are extremely rare. The Wadden Sea, with $350 \mathrm{sq}$. $\mathrm{km}$ of salt marshes, is Europe's prime specimen, as the French Camargue and the Guadalquivir Delta in Spain are too isolated to inspire optimism. And what of the micro-zones that are threatened by individual schemes? 
These very special habitats cannot be put under glass, though concerned scientists talk of management. They advocate grazing use, not only in moderation, but also modulated according to the features of the natural salt marshes. In the case of artificial salt marshes they call for maintenance of breakwaters, with restoration of the biological value of salt marshes behind dikes, by opening them up once again to the sea.

These principles of conservation management will need to be adopted in Nature reserves to be set up along appro- priate coasts. To protect some 1,650 species of invertebrates and over 300 halophilic plants, a genuine European network of biogenetic reserves needs to be established, and quickly.

\author{
MiCHEL GISSY \\ c/o European Information Centre \\ for Nature Conservation \\ Boite Postale: 431 R6 \\ F-67006 Strasbourg Cedex \\ France.
}

\section{Parks Canada-World Heritage Ceremonies}

The World Heritage Convention, established under the auspices of UNESCO, is of growing importance for the conservation of some of the world's most outstanding natural and cultural areas. Eighty-seven nations have joined the convention, and so far 186 areas have been designated World Heritage Sites. Of these, 43 are natural areas.

As a part of Parks Canada's celebration of the centennial of Canada's first National Park, two new World Heritage Sites were added to the six which have been previously designated in Canada; joining Anthony Island (Ninstints Village), Kluane, Nahanni, Dinosaur, Head-smashed-in Buffalo Jump, and L'Anse aux Meadows, were the 'Canadian Rocky Mountain Parks' and Wood Buffalo National Park.

On 21 August 1985, HRH Prince Philip, Duke of Edinburgh, unveiled a plaque commemorating 'The Canadian Rocky Mountain Parks World Heritage Site'. The ceremony attracted a crowd of hundreds in spite of driving rainstorm. This World Heritage Site encompasses Banff, Jasper, Yoho, and Kootenay, National Parks, totalling an area of $20,160 \mathrm{sq} . \mathrm{km}$. At the ceremony, the Government of British Columbia announced its intention of responding positively to the World Heritage Committee's request that Mount Assiniboine, Mount Robson, and Hamber, Provincial Parks be added to the site to enhance its ecological integrity. The World Heritage Plaque has been mounted on the shores of Lake Louise, and will undoubtedly become the subject of millions of tourist photos over the years.
On 22 August 1985 a dual ceremony was held at Fort Smith and Fort Chipweyan, commemorating the designation of Wood Buffalo National Park as a World Heritage Site. Wood Buffalo was recognized for its protection of the endangered Whooping Crane's (Grus americana) nesting areas, the Lake Claire Delta, and its Karst topography.

It seems most unfortunate that press coverage of both these ceremonies indicated a lack of public (or, anyway, press) understanding of the role of the World Heritage Convention. Local press reports suggested that the areas were being internationalized, and that future administration would be under the jurisdiction of UNESCO! These misunderstandings have since been corrected. They do, however, indicate the need for a continuing and more intensive public education programme about the World Heritage Convention and the designation of world heritage sites than has so far been mounted.

Harold K. Eidsvik, Senior Policy Adviser Parks Canada

Ottawa

Ontario K1A 1G2, Canada;

Chairman, (sometime Executive Officer)

Commission on National Parks

IUCN \& Protected Areas

World Conservation Centre

1196 Gland

Switzerland.

\section{Heritage Resources Programme: University of Waterloo-Parks Canada}

Cooperation between government agencies and universities to improve information, research, and training, makes good economic sense. A liaison agreement between Parks Canada and the University of Waterloo, in effect since May 1983, as noted in Environmental Conservation, 11(4), p. 369,1984 , has led to a productive period of strengthening working relationships between Parks $\mathrm{Ca}-$ nada and the Faculty of Environmental Studies, the Department of Recreation and Leisure Studies, and also other departments within the University. Advances have been made particularly in the areas of staff assignments, documentation exchange, an 'occasional paper' series, a publiclecture series, compilation of selected readings, heritage issue sessions, a student internship programme, networking with allied institutions, and a review and compilation of training opportunities for Parks Canada staff that are offered by the University.

A resident Parks Canada liaison officer participates in teaching at the University. In addition, several Parks Canada staff members participate in various courses on a 'guest speaker' basis. Moreover, many students consult with the Parks Canada Liaison Officer on matters of contacts, information, research, career development, and thesis work. A Joint Steering Committee, and a University- based Management Committee, provide direction to the Programme. The public-lecture series and occasional workshops and 'issue' sessions are providing for interaction with interested faculty members, students, and professionals from other Ontario universities, as well as with government and nongovernmental heritage groups.

A collection of government publications has been established at the University, with links to Parks Canada's main documentation centre in Hull, P.Q. Five Occasional Papers have so far been produced and are available at cost. A publications brochure is available on request.

During 1985, the Programme's committee members have been involved in commemorating the one-hundredth anniversary of the establishment of the first Canadian National Park. The Management Committee has advised on a special issue of Environments: Sharing Heritage Management, dedicated to Parks Canada in recognition of the Centennial.

\author{
J. Gordon Nelson, Professor of Geography \\ Heritage Resources Programme \\ University of Waterloo-Parks Canada \\ c/o Faculty of Environmental Studies \\ University of Waterloo \\ Waterloo \\ Ontario N2L 3G1, Canada.
}

